\title{
ANALISIS KOMODITAS UNGGULAN DI WILAYAH KESATUAN PENGELOLAAN HUTAN LINDUNG MODEL HULU SUNGAI SELATAN
}

(Analysis of Main Commodity in Hulu Sungai Selatan Protected Forest Management Unit Model)

\author{
Adnan Ardhana dan Muhammad Abdul Qirom \\ Balai Penelitian dan Pengembangan Lingkungan Hidup dan Kehutanan Banjarbaru \\ Jl. A Yani km 28,7, Landasan Ulin, Banjarbaru, Kalimantan Selatan 70721, Indonesia \\ E-mail: adnan.ardhana@gmail.com
}

Diterima 20 Maret 2017, direvisi 23 Agustus 2017, disetujui 29 Agustus 2017

\begin{abstract}
The objective of the research is to identify which main commodity crops can be developed in three sub-districts, within KPHL Model Hulu Sungai Selatan. The research was carried out during July to December 2016 in three sub-districts, namely: Loksado; Padang Batung; and Telaga Langsat, located within Hulu Sungai Selatan, South Kalimantan. Primary data and secondary data were collected during this research. Secondary data, in the form of time series which includes forest product and horticultural commodities data (food crops, palawija crops, vegetables) during the period of 2011-2015, which refer from Statistics Indonesia (Central Bureau of Statistic). Location Quotient (LQ) and Shif Share Analysis (SSA) method were used to analyze the collected data during this research. The result showed that food crops commodity and food crops sub-sector which become the main commodities of sub-districts within Hulu Sungai Selatan KPHL were peanuts in Loksado sub-district, cassava and paddy in Padang Batung sub-district. For the vegetable sub-sector, there was no main vegetable commodity because it only comparative or competitive advantage. For plantation and forestry commodities, the main commodities in Loksado sub-district were rubber and candlenuts, while for Padang Batung sub-district was rubber plant.
\end{abstract}

Keywords: Protected Forest Management Unit (KPHL) Hulu Sungai Selatan; main commodities, LQ and SSA analysis.

\begin{abstract}
ABSTRAK
Penelitian ini bertujuan untuk mengkaji komoditas unggulan apa saja yang dapat dikembangkan di tiga kecamatan dalam kawasan KPHL Model Hulu Sungai Selatan. Penelitian dilaksanakan pada bulan Juli-Desember 2016 di kecamatan Loksado, kecamatan Padang Batung dan Kecamatan Telaga Langsat,Kabupaten Hulu Sungai Selatan, Provinsi Kalimantan Selatan. Penelitian ini menggunakan data sekunder berupa runtun waktu (time series) yang meliputi jumlah produksi pada komoditas sub sektor pangan dan palawija, sayuran, perkebunan dan kehutanan selama periode 2011-2015 yang berasal dari Badan Pusat Statistik Kabupaten Hulu Sungai Selatan. Alat analisis yang digunakan yaitu analisis Location Quotient (LQ) dan Shift Share Analysis (SSA). Berdasarkan hasil analisis LQ dan SSA, komoditas sub sektor tanaman pangan dan palawija yang menjadi komoditas unggulan kecamatan dalam kawasan KPHL Hulu Sungai Selatan adalah kacang tanah di kecamatan Loksado, ubi kayu dan padi ladang di kecamatan Padang Batung. Untuk sub sektor tanaman sayuran, tidak ditemukan komoditas sayuran unggulan karena hanya memiliki keunggulan komparatif atau keunggulan kompetitif saja. Untuk komoditas tanaman perkebunan dan kehutanan, komoditas unggulan di kecamatan Loksado adalah tanaman karet dan kemiri, sedangkan untuk kecamatan Padang Batung adalah tanaman karet.
\end{abstract}

Kata kunci: KPHL Hulu Sungai Selatan; komoditas unggulan; analisis LQ dan SSA. 


\section{PENDAHULUAN}

Kesatuan Pengelolaan Hutan Lindung (KPHL) Model Hulu Sungai Selatan (HSS) adalah KPHL Model Provinsi Kalimantan Selatan yang dibentuk berdasarkan Surat Keputusan (SK) Menteri Kehutanan Nomor 750/Menhut-II/2012 Tanggal 26 Desember 2012 seluas \pm 32.803 ha yang terdiri dari Hutan Lindung seluas \pm 21.221 ha, Hutan Produksi Terbatas seluas \pm 52 ha dan Hutan Produksi seluas \pm 11.530 ha dimana secara administratif wilayah kerja KPHL Hulu Sungai Selatan meliputi tiga kecamatan yaitu Kecamatan Loksado, Kecamatan Padang Batung dan Kecamatan Telaga Langsat.

Sesuai dengan Peraturan Pemerintah (PP) Nomor 6 Tahun 2007 jo PP Nomor 3 Tahun 2008 Tentang Tata Hutan dan Penyusunan Rencana Pengelolaan Hutan, serta Pemanfaatan Hutan, tugas pokok dan fungsi KPH antara lain adalah melaksanakan kegiatan pengelolaan hutan di wilayahnya mulai dari perencanaan, pengorganisasian, pelaksanaan dan pengawasan serta pengendalian.

Dalam implementasinya, pembangunan $\mathrm{KPH}$ di Indonesia ini ternyata menemui beberapa kendala. Beberapa permasalahan utama yang ditemui di lapangan terkait dengan pembangunan KPH antara lain adalah faktor sosial ekonomi dan kelembagaan yang meliputi belum bersinerginya antara stakeholder yang terkait dalam membangun $\mathrm{KPH}$ dan rancangan perencanaan yang belum optimal, sehingga implementasi pembangunan $\mathrm{KPH}$ yang masih rendah (Suryandari, Alviya, \& Prahasto, 2009 dalam Alviya \& Suryandari, 2009).

Di lain pihak, kenyataan di lapangan menunjukkan banyak masyarakat yang selama ini penghidupannya tergantung pada hutan. Bagi masyarakat, mengelola hutan bukanlah hal yang baru, terutama mereka yang masih memiliki nilai-nilai dan kultur tradisional. Sejak zaman dahulu, masyarakat tidak hanya melihat hutan sebagai sumber daya potensial saja, melainkan memang merupakan sumber pangan, obat-obatan, energi, sandang, lingkungan dan sekaligus tempat tinggal mereka. Bahkan ada sebagian masyarakat tradisional yang meyakini bahwa hutan memiliki nilai spiritual. Sebagai sumber pangan, masyarakat sekitar hutan mengelola lahan dengan pola perladangan untuk ditanami pohon serta pada lantai hutan ditanami dengan tanaman pangan (padi dan palawija). Sebagai sumber obat-obatan dan energi, masyarakat tradisional memanfaatkan tumbuh-tumbuhan liar yang hidup di hutan sebagai bahan obat-obatan dan bahan bakar. Bahan obat ini mereka peroleh dengan cara pemungutan langsung dari alam baik dengan kegiatan pengayaan maupun tanpa pengayaan (Susatijo,2008).

Aktivitas masyarakat tersebut seringkali menimbulkan konflik tersendiri dalam pelaksanaan pembangunan KPH. Konflik dalam kawasan hutan biasanya terjadi akibat tidak jelasnya hak-hak atau hukum yang berhubungan dengan sistem tenurial. Hal ini dapat terjadi antara perorangan, masyarakat, badan/instansi pemerintah atau sektor swasta. Batas-batas kawasan hutan yang belum disepakati bersama oleh masyarakat dan pemerintah juga memicu terjadinya konflik (Sylviani \& Hakim, 2014).

Salah satu peran strategis KPH dalam menjawab tantangan permasalahan dalam pengelolaan hutan antara lain adalah optimalisasi akses masyarakat dalam pengelolaan hutan serta resolusi konflik. Sesuai peraturan perundangan yang berlaku saat ini, keberadaan masyarakat tersebut sebenarnya telah diakomodir keterlibatannya dalam pengelolaan hutan melalui beberapa skema pemberdayaan baik melalui hutan desa, hutan kemasyarakatan, hutan tanaman rakyat maupun dengan kemitraan kehutanan. Lebih lanjut, Ruhimat (2010) menjelaskan bahwa optimasi pemanfaatan dan pengelolaan hutan maupun kawasan hutan bagi kesejahteraan masyarakat dapat dilakukan dengan memegang prinsip bahwa semua hutan dan kawasan hutan harus dikelola dengan tetap 
memerhatikan sifat, karakteristik dan fungsi pokoknya yaitu fungsi konservasi, lindung dan produksi. Oleh karena itu, setiap bentuk pengelolaan hutan dan kawasan hutan harus selalu memerhatikan salah satu fungsi konservasi, lindung, atau produksi.

Berkaitan dengan skema pelibatan masyarakat dalam mengelola hutan tersebut, tentu saja penting untuk dilakukan sebuah kajian komprehensif mengenai komoditaskomoditas apa saja yang menjadi unggulan berdasarkan kondisi riil yang ada di masyarakat. Komoditas unggulan adalah komoditas andalan yang memiliki posisi strategis, dimana berdasarkan pertimbangan teknis (kondisi tanah dan iklim) maupun sosial ekonomi dan kelembagaan (penguasaan teknologi, kemampuan sumber daya manusia, infrastruktur, dan kondisi sosial budaya setempat) layak untuk dikembangkan di suatu wilayah (Badan Litbang Pertanian, 2003; Syahab, Setiawan, \& Syafrial, 2013). Hal ini dikarenakan salah satu faktor yang dapat mendorong pertumbuhan wilayah suatu daerah adalah pemanfaatan kondisi alam dan pertumbuhan basis produksi wilayah bersangkutan (Hamdani, 2016).

Penentuan komoditas unggulan nasional dan daerah merupakan langkah awal menuju pembangunan pertanian yang berpijak pada konsep efisiensi untuk meraih keunggulan komparatif dan kompetitif dalam menghadapi globalisasi perdagangan (Hendayana, 2003). Pendekatan yang dapat digunakan untuk menginisiasi komoditas unggulan adalah Location Quotient (LQ) dan Shift Share Analysis (SSA). Analisis LQ yang diadaptasi dari Miller, Gibson, \& Wright (1991); Isserman (1977); Hood (1998) dalam Hendayana (2003); Sari (2010); dan Sapriadi \& Hasbullah (2015) merupakan cara untuk mengukur kemampuan suatu daerah dalam sektor kegiatan tertentu yang tidak memberikan suatu kesimpulan akhir tetapi sudah memberi gambaran akan kemampuan daerah pada sektor tertentu (Bafadal, 2014). LQ mengukur konsentrasi relatif atau derajat spesialisasi kegiatan ekonomi melalui pendekatan perbandingan. Berdasarkan pemahaman terhadap teori ekonomi basis, teknik LQ relevan digunakan sebagai metode dalam menentukan komoditas unggulan, khususnya dari sisi penawaran (produksi atau populasi) (Simanullang, 2014).

Shift Share Analysis (SSA) merupakan salah satu teknik kuantitatif yang biasa digunakan untuk menganalisis perubahan struktur ekonomi daerah relatif terhadap struktur ekonomi wilayah administratif yang lebih tinggi sebagai pembanding atau referensi. Keunggulan suatu komoditas perlu dievaluasi tidak hanya secara komparatif tetapi dievaluasi juga secara kompetitif (Keratorop,2016). Pemahaman struktur aktivitas dari hasil analisis SSA juga menjelaskan kemampuan berkompetisi (competitiveness) aktivitas tertentu di suatu wilayah secara dinamis atau perubahan aktivitas dalam cakupan wilayah lebih luas. Hasil analisis SSA diperoleh gambaran kinerja aktivitas di suatu wilayah (Kasmadiharja, 2016).

Berdasarkan uraian diatas, tujuan dari penelitian ini untuk mengkaji komoditas unggulan apa saja yang dapat dikembangkan di tiga kecamatan dalam kawasan KPHL Hulu Sungai Selatan. Dengan demikian pada tahapan berikutnya dapat dilakukan arahan dan strategi yang tepat dalam mendukung perkembangan ekonomi masyarakat dalam wilayah KPHL Hulu Sungai Selatan.

\section{METODE PENELITIAN}

\section{A. Pendekatan Penelitian}

Pendekatan yang digunakan dalam penelitian ini adalah deskriptif analisis, yaitu menuturkan pemecahan masalah yang ada sekarang berdasarkan data-data. Data disajikan, dianalisis dan kemudian diinterpretasi (Narbuko \& Achmadi, 1997).

\section{B. Lokasi dan Waktu Penelitian}

Lokasi penelitian ditentukan secara sengaja (purposive) di Kecamatan Loksado, 
Kecamatan Padang Batung dan Kecamatan Telaga Langsat, Kabupaten Hulu Sungai Selatan, Provinsi Kalimantan Selatan karena berada dalam kawasan KPHL Hulu Sungai Selatan. Penelitian dilaksanakan pada bulan Juli sampai dengan Desember 2016.

\section{Data dan Sumber Data}

Data yang dipergunakan dalam penelitian ini adalah data sekunder Kecamatan Loksado, Kecamatan Padang Batung, dan Kecamatan Telaga Langsat yang tersedia di Badan Pusat Statistik Kabupaten Hulu Sungai Selatan. Data yang digunakan meliputi jumlah produksi pada komoditas pertanian sub sektor pangan dan palawija, hortikultura, perkebunan dan kehutanan selama periode 2011-2015.

\section{Analisis Data}

Tahapan analisis yang dilakukan adalah sebagai berikut:

\section{Analisis Location Quotient (LQ)}

Analisis Location Quotient (LQ) digunakan untuk menentukan komoditas yang memiliki keunggulan komparatif. Secara operasional formulasi LQ dapat dirumuskan sebagai berikut(Hendayana, 2003):

$$
L Q=\frac{p i / p t}{P i / P t}
$$

Karena komoditas yang dianalisis berdasarkan produksi, maka notasi-notasi tersebut diartikan sebagai berikut:

$\mathrm{p} i=$ Produksi jenis komoditas i pada tingkat kecamatan

$\mathrm{p} t=$ Total produksi sub sektor komoditas pada tingkat kecamatan

$\mathrm{P} i=$ Produksi jenis komoditas i pada tingkat kabupaten

$\mathrm{P} t=$ Total produksi sub sektor komoditas komoditas pada tingkat kabupaten (Firdaus, Paramu, Suherman, \& Jusuf, 2009; Baladina, Anindita, Isaskar, \& Sukardi, 2013)
Nilai LQ yang diperoleh akan berada dalam kisaran lebih kecil atau sama dengan satu sampai lebih besar dari angka 1, dimana: LQ >1: sektor basis; artinya komoditas i di suatu wilayah memiliki keunggulan komparatif. LQ $=1$ : sektor non-basis; artinya komoditas i di suatu wilayah tidak memiliki keunggulan, produksinya hanya cukup untuk memenuhi kebutuhan wilayah sendiri.

LQ $<1$ : sektor non-basis; artinya komoditas i di suatu wilayah tidak dapat memenuhi kebutuhan sendiri hingga diperlukan pasokan dari luar.

Besaran nilai LQ menunjukkan besaran derajat spesialisasi atau konsentrasi dari komoditas itu di wilayah yang bersangkutan relatif terhadap wilayah referensi. Artinya semakin besar nilai LQ di suatu wilayah, semakin besar pula derajat konsentrasinya di wilayah tersebut.

Apabila analisis nilai LQ dilakukan dengan data time series, maka akan diketahui perkembangan LQ masing-masing komoditas dari tahun ke tahun yang artinya berdasarkan nilai LQ tersebut dapat dikenali komoditas yang konsisten sebagai komoditas yang mempunyai keunggulan komparatif (Tarigan, 2005 dalam Nainggolan \& Aritonang, 2012).

\section{Shift Share Analysis (SSA)}

Shift Share Analysis (SSA) digunakan untuk melihat pertumbuhan produksi sektoral dari suatu kawasan/wilayah. Hasil analisis SSA menjelaskan kemampuan berkompetisi (competitiveness) aktivitas tertentu di suatu wilayah secara dinamis atau perubahan aktivitas dalam cakupan wilayah lebih luas. Kriteria dalam menentukan komoditas yang memiliki keunggulan kompetitif pada penelitian ini adalah jika nilai SSA bernilai positif. Secara matematis metode SSA diformulasikan sebagai berikut (Mulyono, 2015): 


$$
\begin{gathered}
S S A=\left(\frac{X . .(t 1)}{X . .(t 0)}-1\right)+\left(\frac{X i(t 1)}{X i(t 0)}-\frac{X . .(t 1)}{X . .(t 0)}\right. \\
+\left(\frac{X i j(t 1)}{X i j(t 0)}-\frac{X i(t 1)}{X i(t 0)}\right)
\end{gathered}
$$

Keterangan:

$\mathrm{a}=$ komponen regional share

$\mathrm{b}=$ komponen proportional shift

$\mathrm{c}=$ komponen differential shift

$\mathrm{X}=$ nilai total aktivitas dalam total wilayah

$\mathrm{X} i=$ nilai total aktivitas tertentu dalam total wilayah

$\mathrm{X} i j=$ nilai aktivitas tertentu dalam unit wilayah tertentu

$\mathrm{t} 1=$ titik tahun terakhir

t0 = titik tahun awal

Analisis SSA pada penelitian ini menggunakan data produksi masing-masing komoditas kecamatan tahun 2011 sampai dengan 2015 yang bersumber dari Badan Pusat Statistik Kabupaten Hulu Sungai Selatan. Indikator yang menjadi penilaian pada analisis SSA dalam penentuan komoditas unggulan adalah nilai Differential Shift (DS) dimana bila suatu komoditas memiliki nilai DS dalam SSA positif $(>0)$ komoditas tersebut dapat dikatakan memiliki keunggulan kompetitif (Keratorop, 2016).

Dengan demikian kriteria penilaian dalam penentuan komoditas unggulan yang digunakan dalam penelitian ini adalah jika nilai indeks LQ lebih besar atau sama dengan satu (LQ $\geq 1$ ) dan nilai SSA positif (+) (Setiawati, Sitorus, \& Widiatmaka, 2016; Rahman, 2015). Pengolahan dan analisis data tersebut dilakukan secara sederhana menggunakan spreadsheet dari Excel dalam Microsoft Windows.

\section{HASIL DAN PEMBAHASAN}

\section{A. Kondisi Umum KPHL Hulu Sungai Selatan}

Secara administratif wilayah KPHL HSS terletak di Kabupaten Hulu Sungai Selatan.
Total luas unit \pm 32.803 ha yang terdiri atas hutan lindung (HL) seluas \pm 21.221 ha, hutan produksi terbatas (HPT) seluas \pm 52 ha dan hutan produksi (HP) seluas \pm 11.530 ha.

Kelembagaan pengelolaan KPHL berbentuk unit pelaksana teknis daerah (UPTD) yang dipimpin seorang kepala dan berada di bawah kepala dinas. Dalam operasionalisasinya Kepala UPTD dibantu oleh Kepala Sub Bagian Tata Usaha dan kelompok jabatan fungsional.

Secara umum tipologi penutupan lahan di KPHL Hulu Sungai Selatan terdiri atas tujuh tipe yakni belukar, hutan primer, hutan sekunder, hutan tanaman, lahan terbuka, pertanian lahan kering, dan pertanian lahan kering campur semak. Secara rinci kondisi penutupan lahan tersebut dapat dilihat dalam Tabel 1.

Berdasarkan data tersebut, pertanian lahan kering mendominasi penutupan lahan di kawasan KPHL HSS karena mencapai nilai $>50 \%$. Hal ini tentu saja bertolak belakang dengan fungsi kawasan KPHL HSS. Berdasarkan fungsinya, kawasan KPHL Hulu Sungai Selatan terdiri atas dua fungsi, yaitu fungsi lindung dan fungsi produksi, dimana fungsi tersebut didominasi oleh fungsi lindung sebesar $60 \%$ dan fungsi produksi sebesar $40 \%$.

Masyarakat yang berada di sekitar KPHL HSS pada umumnya mempunyai mata pencaharian sebagai petani. Mereka secara turun-temurun telah beraktivitas kegiatan mengelola hutan untuk dijadikan sebagai penunjang penghidupannya. Kegiatan itu meliputi perladangan, perkebunan maupun memanfaatkan hasil hutan non kayu.

\section{B. Analisis LQ Komoditas Tanaman}

\section{Analisis LQ tanaman pangan dan palawija}

Keragaman komoditas tanaman pangan dan palawija pada tiga kecamatan di kawasan KPHL Hulu Sungai Selatan berdasarkan nilai LQ dapat dibagi menjadi dua kriteria yaitu 
Tabel 1. Kondisi penutupan lahan di KPHL HSS

Table 1. Land cover condition in KPHL HSS

\begin{tabular}{|c|c|c|}
\hline $\begin{array}{l}\text { Penutupan lahan } \\
\text { (Land cover) }\end{array}$ & $\begin{array}{l}\text { Luas (Large) } \\
\text { (ha) }\end{array}$ & Persentase (Percentage) (\%) \\
\hline $\begin{array}{l}\text { Belukar } \\
\text { Bushes }\end{array}$ & $4.618,25$ & 14,10 \\
\hline $\begin{array}{l}\text { Hutan primer } \\
\text { Primary forest }\end{array}$ & $2.207,90$ & 6,74 \\
\hline $\begin{array}{l}\text { Hutan sekunder } \\
\text { Secondary forest }\end{array}$ & $1.790,40$ & 5,47 \\
\hline $\begin{array}{l}\text { Hutan tanaman } \\
\text { Plantations }\end{array}$ & 718,50 & 2,19 \\
\hline $\begin{array}{l}\text { Lahan terbuka } \\
\text { Open field }\end{array}$ & 337,20 & 1,03 \\
\hline $\begin{array}{l}\text { Pertambangan } \\
\text { Mining }\end{array}$ & $1.072,90$ & 3,28 \\
\hline $\begin{array}{l}\text { Pertanian lahan kering } \\
\text { Dryland farming }\end{array}$ & 286,10 & 0,87 \\
\hline $\begin{array}{l}\text { Pertanian lahan kering campur semak } \\
\text { Dryland farming with bushes }\end{array}$ & $21.727,65$ & 66,33 \\
\hline Total & $32.758,89$ & 100 \\
\hline
\end{tabular}

Sumber (Source): Ditjen PTKL, 2015

Tabel 2. Nilai LQ produksitanaman pangan dan palawija di Kecamatan Loksado, Padang Batung, dan Telaga Langsat

Table 2. LQ value crop production and food crops in the Sub-district Loksado, Padang Batung, and Telaga Langsat

\begin{tabular}{|c|c|c|c|c|c|c|c|c|c|c|c|c|c|c|c|}
\hline \multirow[t]{2}{*}{ Jenis } & \multicolumn{5}{|c|}{ Loksado } & \multicolumn{5}{|c|}{ Padang Batung } & \multicolumn{5}{|c|}{ Telaga Langsat } \\
\hline & 2011 & 2012 & 2013 & 2014 & 2015 & 2011 & 2012 & 2013 & 2014 & 2015 & 2011 & 2012 & 2013 & 2014 & 2015 \\
\hline $\begin{array}{l}\text { Jagung } \\
\text { Corn }\end{array}$ & 3,6 & 1 & 0,61 & 7,08 & 0,02 & 1,04 & 0,25 & 0,57 & 2,45 & 2,18 & 0,93 & 0,15 & 0,71 & 1,04 & 1,16 \\
\hline $\begin{array}{l}\text { Kacang hijau } \\
\text { Green beans }\end{array}$ & - & - & - & - & - & 0,47 & 0,19 & 0 & 3,28 & 0 & 7,3 & - & - & - & - \\
\hline $\begin{array}{l}\text { Kacang tanah } \\
\text { Peanuts }\end{array}$ & 1,51 & 1,45 & 2,67 & 10,89 & 5,21 & 6,1 & 6,7 & 6,71 & 9,1 & 10,89 & 0,49 & 0,05 & 2,6 & 0 & 0,48 \\
\hline $\begin{array}{l}\text { Kedelai } \\
\text { Soy }\end{array}$ & - & - & 1,28 & 31,44 & - & 1,07 & 1,04 & 2,13 & 4,98 & 0 & 4,69 & 5 & - & - & - \\
\hline $\begin{array}{l}\text { Padi ladang } \\
\text { Field rice }\end{array}$ & 9,12 & 11,64 & 10,34 & 11,08 & 10,12 & 1,48 & 2,33 & 2,73 & 2,22 & 3,04 & 1,42 & 2,7 & 2,45 & 1,54 & 2,02 \\
\hline $\begin{array}{l}\text { Padi sawah } \\
\text { Paddy rice }\end{array}$ & 0,01 & 0,03 & 0,01 & 0,03 & - & 0,91 & 0,89 & 0,81 & 0,85 & 0,71 & 0,96 & 0,9 & 0,87 & 0,97 & 0,91 \\
\hline $\begin{array}{l}\text { Ubi jalar } \\
\text { Sweet potato } \\
\text { Ubi kayu }\end{array}$ & - & - & - & - & - & 0,07 & 0,07 & 0,25 & 0,56 & 0,6 & 0,13 & & - & - & - \\
\hline Cassava & 0,89 & 1,36 & 1,39 & 2,45 & 12,64 & 2,84 & 3,78 & 3,57 & 3,06 & 5,7 & 1,85 & 1,85 & 2,82 & 1,71 & 1,41 \\
\hline
\end{tabular}

Sumber (Source): BPS Kabupaten Hulu Sungai Selatan (diolah), 2012, 2013, 2014, 2015, 2016

nilai $\mathrm{LQ}>1$ (basis) dan nilai $\mathrm{LQ}<1$ (non basis) disajikan dalam Tabel 2.

Persepsi dan perilaku seseorang adalah bentuk karakteristik sosial yang banyak dipertimbangkan untuk mengelola kawasan hutan berbasis masyarakat. Mamuko, Walangitan, \& Tilaar (2016) meyatakan bahwa keberhasilan program rehabilitasi hutan dan lahan sangat dipengaruhi oleh banyak faktor, baik faktor teknis, kelembagaan maupun 
Tabel 3. Nilai LQ produksi tanaman sayuran di Kecamatan Loksado, Padang Batung, dan Telaga Langsat Table 3. LQ value of vegetable crops production in the Sub-district Loksado, Padang Batung, and Telaga Langsat

\begin{tabular}{|c|c|c|c|c|c|c|c|c|c|c|c|c|c|c|c|}
\hline \multirow[t]{2}{*}{ Komoditas } & \multicolumn{5}{|c|}{ Loksado } & \multicolumn{5}{|c|}{ Padang Batung } & \multicolumn{5}{|c|}{ Telaga Langsat } \\
\hline & 2011 & 2012 & 2013 & 2014 & 2015 & 2011 & 2012 & 2013 & 2014 & 2015 & 2011 & 2012 & 2013 & 2014 & 2015 \\
\hline Buncis & & & & & & & & & & & & & & & \\
\hline Bean & - & - & - & - & 1,75 & - & - & - & - & - & - & - & - & - & - \\
\hline $\begin{array}{l}\text { Cabe besar } \\
\text { Chilli }\end{array}$ & - & 2,07 & 0 & 1,98 & 1,21 & 1,27 & 0,65 & 0,58 & 0,62 & 0,97 & 0,75 & 0,65 & 0,54 & 0,62 & 0,54 \\
\hline $\begin{array}{l}\text { Kacang } \\
\text { panjang }\end{array}$ & & & & & & & & & & & & & & & \\
\hline Long bean & 4,49 & 0,52 & 2,69 & - & 1 & 0,32 & 0,86 & 0,87 & 0,92 & 0,88 & 3,32 & 2,7 & 2,49 & 2,73 & 2,36 \\
\hline Ketimun & & & & & & & & & & & & & & & \\
\hline $\begin{array}{l}\text { Cucumber } \\
\text { Sawi }\end{array}$ & - & - & - & - & 0,73 & - & - & - & - & - & - & - & - & - & - \\
\hline $\begin{array}{l}\text { Mustard } \\
\text { Terong }\end{array}$ & - & - & - & - & - & 2,83 & 188,83 & 4,06 & 4,19 & 3,01 & - & - & - & - & - \\
\hline $\begin{array}{l}\text { Eggplant } \\
\text { Tomat }\end{array}$ & 1,95 & 1,25 & 2,13 & 1,36 & 0,1 & 0,19 & 0,38 & 0,38 & 0,32 & 0,31 & 0,27 & 0,68 & 1,75 & 1,38 & 1 \\
\hline Tomato & - & 0,34 & - & 0,33 & - & 1,86 & 1,86 & 1,97 & 1,7 & 1,46 & 1,03 & 0,69 & 0,46 & 0,79 & 0,8 \\
\hline
\end{tabular}

Sumber (Source): BPS Kabupaten Hulu Sungai Selatan (diolah), 2012, 2013, 2014, 2015, 2016

faktor sosial ekonomi masyarakat. Dari aspek teknis, kendala yang dihadapi diantaranya adalah kondisi iklim, tanah dan aspek ekologis lainnya, sedangkan dari aspek kelembagaan sering diperhadapkan pada hambatan pelaksanaan kegiatan karena mengikuti prosedur keproyekan. Dari aspek sosial ekonomi keberhasilan program dipengaruhi oleh persepsi dan perilaku sebagai faktor yang mendorong tingkat partisipasi masyarakat. Beberapa indikator yang digunakan untuk mengetahui tingkat persepsi dan perilaku masyarakat Desa Lolan dalam penelitian ini ditampilkan pada Tabel 2.

Berdasarkan tabel tersebut terdapat delapan komoditas tanaman pangan dan palawija yang diusahakan pada tiga kecamatan di kawasan KPHL Hulu Sungai Selatan yaitu padi sawah, padi ladang, jagung, kedelai, kacang tanah, kacang hijau, ubi jalar dan ubi kayu. Hasil analisis LQ, komoditas yang memiliki keunggulan komparatif di Kecamatan Loksado adalah padi ladang dan kacang tanah, sedangkan untuk Kecamatan Padang Batung adalah komoditas padi ladang, ubi kayu dan kacang tanah dan di Kecamatan Telaga Langsat adalah komoditas padi ladang dan ubi kayu karena memiliki nilai konsisten $>1$ selama 5 tahun.

\section{Analisis LQ komoditas sayuran}

Keragaman komoditas sayuran tiap kecamatan berdasarkan nilai LQ disajikan dalam Tabel 3.

Berdasarkan Tabel 3, komoditas sayuran yang diusahakan oleh masyarakat di tiga kecamatan dalam wilayah KPHL Hulu Sungai Selatan terdapat tujuh jenis yaitu kacang panjang, cabe besar, sawi, terong, tomat, buncis dan ketimun. Hasil analisis LQ menunjukkan di Kecamatan Loksado tidak terdapat komoditas sayuran yang mempunyai keunggulan komparatif karena tidak ada yang memiliki nilai LQ $>1$ secara konsisten dalam lima tahun. Di Kecamatan Padang Batung, komoditas yang memiliki keunggulan komparatif adalah kacang panjang dan di Kecamatan Telaga Langsat adalah sawi dan tomat.

\section{Analisis LQ tanaman perkebunan dan kehutanan}

Keragaman tanaman perkebunan dan kehutanan pada tiga kecamatan di kawasan KPHL Hulu Sungai Selatan disajikan dalam Tabel 4.

Berdasarkan Tabel 4, komoditas tanaman perkebunan dan kehutanan yang diusahakan masyarakat di tiga kecamatan dalam kawasan 
Tabel 4.Nilai LQ produksi tanaman perkebunan dan kehutanan di Kecamatan Loksado, Padang Batung, dan Telaga Langsat

Table 4. LQ value of plantation dan forestry production in the Sub-district Loksado, Padang Batung, and Telaga Langsat

\begin{tabular}{|c|c|c|c|c|c|c|c|c|c|c|c|c|c|c|c|}
\hline \multirow[t]{2}{*}{ Komoditas } & \multicolumn{5}{|c|}{ Loksado } & \multicolumn{5}{|c|}{ Padang Batung } & \multicolumn{5}{|c|}{ Telaga Langsat } \\
\hline & 2011 & 2012 & 2013 & 2014 & 2015 & 2011 & 2012 & 2013 & 2014 & 2015 & 2011 & 2012 & 2013 & 2014 & 2015 \\
\hline $\begin{array}{l}\text { Aren } \\
\text { Aren }\end{array}$ & 0,02 & 0,07 & 0,07 & 0,04 & 2,13 & 0 & 3,15 & 1,55 & 2,54 & 3,9 & 0,51 & 4,08 & 3,01 & 3,21 & 5,04 \\
\hline $\begin{array}{l}\text { Cengkeh } \\
\text { Clove }\end{array}$ & 0,07 & 0,99 & 0,94 & 0,52 & 1,02 & - & - & - & - & - & 0,2 & 3,67 & 2,74 & 2,92 & 4,9 \\
\hline $\begin{array}{l}\text { Kakao } \\
\text { Cocoa }\end{array}$ & - & - & - & - & - & - & - & - & - & - & 1,74 & 1,85 & 1,18 & 1,26 & 1,72 \\
\hline $\begin{array}{l}\text { Karet } \\
\text { Rubber }\end{array}$ & 2,06 & 1,24 & 1,2 & 1,44 & 1,37 & 1,76 & 2,32 & 1,21 & 1,56 & 2,3 & 1,78 & 1,42 & 1,2 & 1,19 & 1,41 \\
\hline $\begin{array}{l}\text { Kayu manis } \\
\text { Cinnamon }\end{array}$ & 1,38 & 2,16 & 2,08 & 1,23 & 2,19 & - & - & - & - & - & - & 0,02 & - & - & 0,03 \\
\hline $\begin{array}{l}\text { Kelapa dalam } \\
\text { Coconut }\end{array}$ & 0,01 & 0,01 & 0,01 & 0,01 & 0,02 & 0,61 & 0,1 & 1,6 & 0,35 & 0,13 & 0,8 & 0,97 & 0,84 & 0,89 & 1,21 \\
\hline $\begin{array}{l}\text { Kelapa sawit } \\
\text { Palm oil } \\
\text { Kemiri }\end{array}$ & 0,78 & 1,54 & 1,18 & 0,63 & 1,05 & 1,1 & 0,77 & 0,76 & 1,17 & 0,53 & 0,59 & 0,74 & 1,1 & 1,12 & 0,51 \\
\hline $\begin{array}{l}\text { Candlenut } \\
\text { Kopi }\end{array}$ & 3,05 & 2,25 & 2,23 & 1,24 & 9,46 & - & 0,01 & 0 & 0 & 0,01 & 0,13 & 0,17 & 0,13 & 0,14 & 0,21 \\
\hline Coffe & 0,23 & 0,31 & 0,07 & 0,17 & 0,99 & - & 0,59 & 0,3 & 0,48 & 5,55 & 3,55 & 5,4 & 4,07 & 4,34 & 50,94 \\
\hline $\begin{array}{l}\text { Lada } \\
\text { Pepper }\end{array}$ & 0,59 & 1,45 & 1,17 & 0,65 & 1,16 & - & - & - & - & - & 0,89 & 3,2 & 2,01 & 2,15 & 6,08 \\
\hline
\end{tabular}

Sumber (Source): BPS Kabupaten Hulu Sungai Selatan (diolah), 2012, 2013, 2014, 2015, 2016

KPHL HSS terdapat 10 jenis yaitu karet, kayu manis, kelapa dalam, kopi, cengkeh, lada, kemiri, aren, kakao dan kelapa sawit. Dari analisis LQ, komoditas yang memiliki keunggulan komparatif di Kecamatan Loksado adalah tanaman karet, kemiri dan kayu manis. Untuk Kecamatan Padang Batung adalah komoditas karet, kakao dan kopi serta di Kecamatan Telaga Langsat adalah tanaman karet.

\section{Analisis SSA}

Melengkapi hasil analisis LQ dalam penentuan komoditas unggulan di tiga kecamatan di wilayah KPHL Hulu Sungai Selatan maka juga dilakukan perhitungan Shift Share Analysis (SSA). Dalam penelitian ini metode Shift Share Analysis digunakan untuk melihat komoditas unggulan kompetitif masing-masing komoditas. Berdasarkan indikator Differential Shift pada analisis SSA, komoditas yang memiliki keunggulan kompetitif karena memiliki nilai DS positif
$(>0)$ setiap kecamatan disajikan dalam Tabel 5 .

Berdasarkan Tabel 5 di atas, komoditas tanaman pangan dan palawija yang memiliki keunggulan kompetitif di Kecamatan Loksado adalah kacang tanah dan ubi kayu. Untuk kecamatan Padang Batung adalah padi ladang, jagung, ubi kayu dan ubi jalar serta untuk Kecamatan Telaga Langsat adalah padi sawah dan jagung karena memiliki nilai DS positif $(>0)$.

Hasil analisis SSA untuk tanaman sayuran, komoditas yang memiliki nilai DS positif di Kecamatan Loksado adalah komoditas kacang panjang dan terong. Di Kecamatan Padang Batung tidak ditemukan komoditas yang memiliki nilai DS positif, sedangkan di Kecamatan Telaga Langsat yang memiliki nilai DS positif adalah komoditas kacang panjang. Sedangkan untuk tanaman perkebunan dan kehutanan, komoditas yang memiliki nilai DS positif di Kecamatan Loksado adalah komoditas karet, kelapa dalam, cengkeh, 
Tabel 5. Nilai DS produksi tiap komoditas di Kecamatan Loksado, Padang Batung dan Telaga Langsat

Table 5. DS value of production of each commodity in the Sub-district Loksado, Padang Batung and Telaga Langsat

\begin{tabular}{|c|c|c|c|}
\hline \multirow{2}{*}{$\begin{array}{l}\text { Komoditas } \\
\text { (Commodity) }\end{array}$} & \multicolumn{3}{|c|}{ Kecamatan (Sub-district) } \\
\hline & Loksado & Telaga Langsat & Padang Batung \\
\hline \multicolumn{4}{|c|}{ Pangan dan palawija (food and food crop) } \\
\hline Padi sawah (Paddy rice) & $-0,267$ & $-0,061$ & $-0,061$ \\
\hline Padi ladang (Field rice) & $-0,030$ & 0,252 & 0,252 \\
\hline Jagung (Corn) & $-0,522$ & 0,872 & 0,872 \\
\hline Ubi kayu (Cassava) & 0,216 & 0,170 & 0,170 \\
\hline Ubi jalar (Sweet potato) & - & 3,792 & 3,792 \\
\hline Kacang tanah (Peanuts) & 1,041 & $-0,130$ & $-0,130$ \\
\hline Kedelai (Soy) & - & - & - \\
\hline Kacang hijau (Green bean) & $-0,933$ & $-0,933$ & $-0,933$ \\
\hline \multicolumn{4}{|l|}{ Sayuran(Vegetables) } \\
\hline Cabe besar (Chilli) & $-1,023$ & $-0,209$ & $-0,186$ \\
\hline Kacang panjang (Long bean) & 8,793 & 1,292 & $-0,394$ \\
\hline Sawi (Mustard) & 31,643 & $-0,770$ & $-0,191$ \\
\hline Terong (Eggplant) & 0,390 & $-0,005$ & 0,022 \\
\hline Tomat (Tomato) & 0,151 & - & - \\
\hline \multicolumn{4}{|c|}{ Perkebunan dan kehutanan(Plantation and Forestry) } \\
\hline Karet (Rubber) & 0,298 & $-0,398$ & $-0,383$ \\
\hline Kelapa sawit (Palm oil) & 1,343 & $-1,830$ & $-1,146$ \\
\hline Kelapa dalam (Coconut) & 2,846 & $-0,635$ & 0,282 \\
\hline Lada (Pepper) & $-0,451$ & $-2,176$ & 0,530 \\
\hline Kopi (Coffee) & $-0,650$ & $-1,970$ & $-0,001$ \\
\hline Kakao (Cocoa) & $-0,800$ & $-0,800$ & - \\
\hline Aren (Aren) & 0,492 & $-1,464$ & $-0,335$ \\
\hline Kemiri (Candlenut) & 0,001 & $-1,041$ & $-0,041$ \\
\hline Cengkeh (Clove) & 0,158 & $-0,851$ & $-0,097$ \\
\hline Kayu manis (Cinnamon) & $-0,007$ & - & $-2,349$ \\
\hline
\end{tabular}

Sumber (Source): BPS Kabupaten Hulu Sungai Selatan (diolah), 2012, 2013, 2014, 2015, 2016

kemiri, aren, dan kelapa sawit. Untuk Kecamatan Padang Batung adalah komoditas kelapa dalam dan lada, sedangkan untuk Kecamatan Telaga Langsat tidak ditemukan komoditas yang memiliki nilai DS positif

\section{Komoditas Unggulan di 3 (tiga) Kecamatan dalam Wilayah KPHL Hulu Sungai Selatan}

Untuk menentukan komoditas unggulan pertanian dapat dilihat dari kombinasi nilai LQ dan SSA. Jika nilai LQ $>1$ dan nilai SSAnya $>0(+)$, maka komoditas tersebut dikatakan unggul. Komoditas yang dikatakan unggul tersebut mempunyai pemusatan aktivitas di wilayah tertentu dan mampu menyediakan suplai komoditas ke wilayah yang lain serta komoditas tersebut mengalami pertumbuhan yang signifikan dari waktu ke waktu. 
1. Komoditas unggulan tanaman pangan dan palawija

Berdasarkan hasil analisis LQ dan SSA, komoditas unggulan tanaman pangan dan palawija di Kecamatan Loksado adalah kacang tanah, komoditas unggulan tanaman pangan dan palawija Kecamatan Padang Batung adalah padi ladang dan ubi kayu karena memiliki nilai $L Q \geq 1$ dan nilai $D S$ positif $(+)$, sedangkan di Kecamatan Telaga Langsat tidak ditemukan komoditas unggulan karena hanya memiliki keunggulan komparatif atau pun keunggulan kompetitif saja. Secara lebih terinci komoditas yang memiliki keunggulan komparatif dan kompetitif di masing-masing kecamatan disajikan dalam Tabel 6 .

Dengan demikian sebagai langkah awal pengembangan komoditas pangan dan palawija di Kecamatan Loksado adalah kacang tanah, Kecamatan Padang Batung adalah padi ladang dan ubi kayu karena sudah menguasai teknologi budidaya tanaman tersebut.
2. Komoditas unggulan tanaman sayuran

Berdasarkan hasil analisis LQ dan SSA (Tabel 6), komoditas unggulan tanaman sayuran tidak ditemukan yang menjadi unggulan di kecamatan dalam wilayah KPHL Hulu Sungai Selatan. Hal ini disebabkan karena komoditas yang dianalisis hanya memiliki keunggulan komparatif saja, seperti komoditas kacang panjang di Kecamatan Padang Batung, sawi dan tomat di Kecamatan Telaga Langsat, ataupun hanya memiliki keunggulan kompetitif seperti komoditas kacang panjang dan terong di Kecamatan Loksado.

3. Komoditas unggulan tanaman perkebunan dan kehutanan

Hasil analisis LQ dan SSA (Tabel 6) untuk komoditas perkebunan dan kehutanan di masing-masing kecamatan menunjukkan bahwa komoditas yang menjadi unggulan di Kecamatan Loksado adalah karet dan kemiri, di Kecamatan Padang Batung danKecamatan

Tabel 6. Komoditas unggulan tanaman pangan dan palawija, Sayuran, Perkebunan dan Kehutanan di Kecamatan Loksado, Telaga Langsat, dan Padang Batung

Table 6. Main commodities of crop and food crops, vegetable, plantation and forestry in the sub-districtLoksado, Telaga Langsat, and Padang Batung

\begin{tabular}{|c|c|c|c|c|}
\hline \multirow{2}{*}{$\begin{array}{l}\text { Sub Sektor } \\
(\text { Sub Sector })\end{array}$} & \multirow{2}{*}{$\begin{array}{l}\text { Kecamatan } \\
\text { (Sub-district) }\end{array}$} & \multicolumn{2}{|c|}{ Komoditas (Comodity) } & \multirow{2}{*}{$\begin{array}{l}\text { Komoditas unggulan } \\
\text { (Main commodity) }\end{array}$} \\
\hline & & $\mathrm{LQ} \geq 1$ & SSA $(+)$ & \\
\hline \multirow{3}{*}{$\begin{array}{l}\text { Tanaman } \\
\text { Pangan dan } \\
\text { Palawija }\end{array}$} & Loksado & padi ladang, kacang tanah & kacang tanah, ubi kayu & kacang tanah \\
\hline & $\begin{array}{l}\text { Telaga } \\
\text { langsat }\end{array}$ & padi ladang, ubi kayu & padi sawah, jagung & tidak ada \\
\hline & $\begin{array}{l}\text { Padang } \\
\text { Batung }\end{array}$ & $\begin{array}{l}\text { padi ladang, ubi kayu, } \\
\text { kacang tanah }\end{array}$ & $\begin{array}{l}\text { padi ladang, jagung, ubi } \\
\text { kayu, ubi jalar }\end{array}$ & padi ladang, ubi kayu \\
\hline \multirow{3}{*}{$\begin{array}{l}\text { Tanaman } \\
\text { Sayuran }\end{array}$} & Loksado & tidak ada & kacang panjang, terong & tidak ada \\
\hline & $\begin{array}{l}\text { Telaga } \\
\text { Langsat }\end{array}$ & sawi, tomat & kacang panjang & tidak ada \\
\hline & $\begin{array}{l}\text { Padang } \\
\text { Batung }\end{array}$ & kacang panjang & tidak ada & tidak ada \\
\hline \multirow[t]{3}{*}{$\begin{array}{l}\text { Perkebunan } \\
\text { dan } \\
\text { Kehutanan }\end{array}$} & Loksado & karet, kemiri, kayu manis & $\begin{array}{l}\text { karet, kelapa dalam, } \\
\text { cengkeh, kemiri, aren, } \\
\text { kelapa sawit }\end{array}$ & Karet, kemiri \\
\hline & $\begin{array}{l}\text { Telaga } \\
\text { Langsat }\end{array}$ & karet & tidak ada & tidak ada \\
\hline & $\begin{array}{l}\text { Padang } \\
\text { Batung }\end{array}$ & karet, kakao, kopi & kelapa dalam, lada & tidak ada \\
\hline
\end{tabular}

Sumber (Source): BPS Kabupaten Hulu Sungai Selatan (diolah), 2012, 2013, 2014, 2015, 2016 
Telaga Langsat tidak ditemukan komoditas yang menjadi unggulan. Dengan demikian sebagai langkah awal pengembangan komoditas perkebunan dan kehutanan di Kecamatan Loksado adalah karet dan kemiri karena sudah menguasai teknologi budidaya tanaman tersebut.

\section{E. Implikasi}

Pada dasarnya pembangunan KPH adalah untuk mewujudkan pengelolaan hutan secara efisien dan lestari. Hal tersebut juga tercantum dalam tujuan pengelolaan KPHL Hulu Sungai Selatan dalam draft dokumen Rencana Pengelolaan Jangka Panjang Kesatuan Pengelolaan Hutan Lindung (RPJP KPHL) Hulu Sungai Selatan yaitu: 1) Mewujudkan kelembagaan KPHL Model HSS sebagai pengelola hutan yang profesional, meliputi sumber daya manusia pengelola, menyusun struktur organisasi, fungsi, wewenang, tugas dan tanggungjawab serta tata hubungan kerja dan kemitraan dalam rangka efektivitas pengelolaan hutan pada wilayah KPHL Model HSS; 2) Optimalisasi fungsi dan manfaat dari ekosistem hutan pada wilayah KPHL Model HSS dalam rangka peningkatan produktivitas wilayah; 3) Terwujudnya keterwakilan dan kepentingan masyarakat serta para pihak yang proporsional dalam pengelolaan dan pemanfaatan hutan lestari dan 4) Optimalisasi produksi hasil hutan kayu, HHBK, dan jasa lingkungan untuk memperoleh manfaat ekonomi.

Untuk mewujudkan tujuan tersebut tentunya diperlukan pemahaman yang akurat terkait kondisi dilapangan secara komprehensif. Hasil temuan yang terkait dengan komoditas tanaman baik pangan, palawija, sayuran, perkebunan maupun kehutanan dapat menjadi salah pintu masuk pengembangan ekonomi lokal masyarakat untuk turut serta dalam pengelolaan hutan di kawasan KPHL HSS. Pengembangan ekonomi lokal pada dasarnya adalah proses yang membentuk kemitraan pelaku (stakeholders) ekonomi, yakni pemerintah daerah, kelompok-kelompok berbasis masyarakat dan sektor swasta dalam mengelola sumber daya yang tersedia untuk menciptakan lapangan kerja dan menggiatkan ekonomi daerah. Pendekatan tersebut menekankan kewenangan lokal, menggunakan potensi sumber daya manusia, sumber daya fisik dan kelembagaan. Kemitraan pengembangan ekonomi lokal mengintegrasikan upaya mobilisasi para pelaku, organisasi dan sumber daya, serta pengembangan kelembagaan baru melalui dialog dan kegiatan-kegiatan strategik (Dendi, Heile, Mahman, Hilaliyah, \& Haryono, 2004)

Pola tanaman campuran atau agroforestri dapat dijadikan pilihan pengembangan mengingat beberapa komoditas memerlukan sinar matahari terbuka. Pola tersebut dapat dikembangkan melalui skema hutan desa dibandingkan hutan kemasyarakatan mengingat kondisi keinginan masyarakat yang selalu berubah dan dipengaruhi oleh faktor eksternal (Qirom, Lazuardi, \& Ardhana, 2016).

\section{KESIMPULAN DAN SARAN}

\section{A. Kesimpulan}

Komoditas sub sektor tanaman pangan dan palawija yang menjadi komoditas unggulan di Kecamatan Loksado adalah kacang tanah, di Kecamatan Padang Batung adalah padi ladang dan ubi kayu. Untuk komoditas sayuran, tidak ditemukan komoditas yang menjadi unggulan di kecamatan dalam wilayah KPHL Hulu Sungai Selatan. Hal ini disebabkan karena komoditas yang dianalisis hanya memiliki keunggulan komparatif atau keunggulan kompetitif saja dan untuk komoditas perkebunan dan kehutanan, komoditas unggulan di Kecamatan Loksado adalah karet dan kemiri dan di Kecamatan Padang Batung adalah komoditas karet.

\section{B. Saran}

Jenis-jenis karet dan kemiri menjadi alternatif dalam pembangunan agroforestri 
di KPHL HSS. Jenis-jenis tersebut dikombinasikan dengan tanaman pangan seperti padi, kacang tanah, dan ubi kayu. Namun, penelitian lanjutan mengenai kajian kesesuaian jenis, kombinasi tanaman dalam pola agroforestri dan perencanaan penggunaan lahan berdasarkan daya dukung wilayah untuk pengembangan komoditas yang menjadi unggulan atau pun yang berpotensi menjadi komoditas unggulan di wilayah KPHL Hulu Sungai Selatan perlu dilakukan agartingkat produksi menjadi maksimal dan berkelanjutan.

\section{UCAPAN TERIMA KASIH (ACKNOWLEDGEMENT)}

Artikel ilmiah ini merupakan bagian dari Laporan Penelitian Strategi Pengelolaan KPHL Hulu Sungai Selatan tahun 20152019. Untuk itu penulis mengucapkan terima kasih kepada Kepala Balai Penelitian dan Pengembangan Lingkungan Hidup dan Kehutanan Banjarbaru, Ir. Tjuk Sasmito Hadi, M.Sc yang telah memberikan kesempatan melakukan penelitian ini pada tahun 2015 dan 2016, Kepala KPHL Hulu Sungai Selatan beserta staf atas fasilitasi kegiatan penelitian, BPS Hulu Sungai Selatan atas data yang diberikan. Ucapan terima kasih juga disampaikan kepada tim peneliti Strategi Pengelolaan KPHL Hulu Sungai Selatan atas kerja samanya selama ini.

\section{DAFTAR PUSTAKA}

Alviya, I. \& Suryandari, E. Y. (2009). Kendala dan strategi implementasi pembangunan $\mathrm{KPH}$ Rinjani Barat. Jurnal Penelitian Sosial dan Ekonomi Kehutanan, 6(1), 1-14.

Badan Litbang Pertanian. (2003). Panduan umum pelaksanaan pengkajian program informasi komunikasi dan desiminasi BPTP Badan Penelitian \& Pengembangan Pertanian. Bogor: Kementerian Pertanian.

Bafadal, A. (2014). Analisis sektor basis pertanian untuk pengembangan ekonomi daerah.
AGRIPLUS, 24(2).

Baladina, N., Anindita, R., Isaskar, R., \& Sukardi. (2013). Identifikasi potensi komoditi pertanian unggulan dalam penerapan konsep agropolitan di Kecamatan Poncokusumo, Kabupaten Malang. AGRISE, XIII(3), 14121425.

BPS Kabupaten Hulu Sungai Selatan. (2011). Hulu Sungai Selatan dalam Angka 2011. Kandangan: BPS Kabupaten Hulu Sungai Selatan.

BPS Kabupaten Hulu Sungai Selatan. (2013). Hulu Sungai Selatan dalam Angka 2012. Kandangan: BPS Kabupaten Hulu Sungai Selatan.

BPS Kabupaten Hulu Sungai Selatan. (2014). Hulu Sungai Selatan dalam Angka 2013. Kandangan: BPS Kabupaten Hulu Sungai Selatan.

BPS Kabupaten Hulu Sungai Selatan. (2015). Hulu Sungai Selatan dalam Angka 2014. Kandangan: BPS Kabupaten Hulu Sungai Selatan.

BPS Kabupaten Hulu Sungai Selatan. (2016). Hulu Sungai Selatan dalam Angka 2015. Kandangan: BPS Kabupaten Hulu Sungai Selatan.

Dendi, A., Heile, H., Mahman, Hilaliyah, R., \& Haryono, R. S. (2004). Menanggulangi kemiskinan melalui pengembangan ekonomi lokal beberapa pelajaran dari Nusa Tenggara. Jakarta: Ditjen Bina Pembangunan Daerah Departemen Dalam Negeri dan GTZ.

Firdaus, M., Paramu, H., Suherman, \& Jusuf, C. (2009). Penentuan Komoditas Pertanian Unggulan Di Kabupaten Jember. JSEP, 3(1), 33-39.

Hamdani, A. F. (2016). Analisis location quotient (LQ) agropolitan poncokusumo. Jurnal Pendidikan Geografi, 1(1), 44-50.

Hendayana, R. (2003). Aplikasi metode location quotient (LQ) dalam penentuan komoditas unggulan nasional. Informatika Pertanian, 12(2003), 1-21.

Isserman, A. M. (1977). The location quotient approach to estimating regional economic impacts. Journal of the American Institute of Planners, 43(1), 33-41. https://doi. org/10.1080/01944367708977758

Kasmadiharja, H. (2016). Arahan pengembangan kawasan agropolitan berbasis komoditas sayuran unggulan di Kabupaten Agam. (Tesis). Bogor: Institut Pertanian Bogor. 
Keratorop, M. (2016). Arahan pengembangan komoditas unggulan pertanian tanaman pangan di Kabupaten Boven Digoel, Provinsi Papua. (Tesis). Bogor: Institut Pertanian Bogor.

Miller, M. M., Gibson, L. J., \& Wright, N. G. (1991). Location quotient: A basic tool for economic development analysis. Economic Development Review, 9, 65-68.

Mulyono, J. (2015). Strategi pembangunan sektor pertanian di zona agro ekologi (ZAE) kawasan perdesaan Kabupaten Bantul. (Tesis). Bogor: Institut Pertanian Bogor.

Nainggolan, H. L., \& Aritonang, J. (2012). Pengembangan pertanian berbasis komoditi unggulan dalam rangka pembangunan berkelanjutan studi kasus Kabupaten Humbang Hasundutan. Prosiding Seminar Nasional Tantangan Pembangunan Berkelanjutan dan Perubahan Iklim di Indonesia (p. 337). Medan 02 Juni 2012. Kerja Sama BLH Sumatera Utara dengan Program Studi PSL SPS USU Medan.

Narbuko, C., \& Achmadi, A. (1997). Metodologi penelitian. Jakarta: Bumi Aksara.

Qirom, M. A., Lazuardi, D., \& Ardhana, A. (2016). Pengelolaan dan pengusahaan KPHL bebasis ekosistem (Kasus di Hulu Sungai Selatan). (Laporan Hasil Penelitian Tahun 2016). Banjarbaru: Balai Penelitian dan Pengembangan Lingkungan Hidup dan Kehutanan Banjarbaru.

Rahman, R. (2015). Perencanaan penggunaan lahan pertanian berbasis komoditas unggulan di wilayah Boliyohuto Kabupaten Gorontalo. (Tesis). Bogor: Institut Pertanian Bogor.
Ruhimat, I. S. (2010). Implementasi kebijakan kesatuan pengelolaan hutan (KPH) di Kabupaten Banjar. Jurnal Analisis Kebijakan Kehutanan, 7(2), 169-178.

Sapriadi \& Hasbullah. (2015). Analisis penentuan sektor unggulan perekonomian Kabupaten Bulukumba. Iqtisaduna, 1(1), 71-86.

Sari, R. M. (2010). Analisis komoditas unggulan pertanian di Pulau Buru Provinsi Maluku. Jurnal Agroforestri, V(3), 228-236.

Setiawati, A. R., Sitorus, S. R. P., \& Widiatmaka. (2016). Perencanaan penggunaan lahan komoditas unggulan perkebunan di Kabupaten Tanah Datar. Tata Loka, 18(3), 131-140.

Simanullang, M. (2014). Analisis komoditas unggulan sub sektor hortikultura di Provinsi Sumatera Utara. (Tesis).Medan: Universitas Sumatera Utara.

Susatijo, B. (2008). Hutan sebagai alternatif lumbung pangan. Retrieved December 12, 2016 from http://dishut.jabarprov.go.id/images/ artikel/Hutan Sebagai Salah Satu Alternatif Lumbung.doc

Syahab, A., Setiawan, B., \& Syafrial. (2013). Analisis pengembangan komoditi unggulan tanaman pangan di Kabupaten Sumbawa. AGRISE, 13(2).

Sylviani \& Hakim, I. (2014). Analisis tenurial dalam pengembangan kesatuan pengelolaan hutan (KPH): Studi kasus KPH Gedong Wani. Jurnal Penelitian Sosial dan Ekonomi Kehutanan, 11(4), 309-322. 